\title{
REVISITING WILLIAM BLAKE'S \\ MARRIAGE OF HEAVEN AND HELL: \\ A READING AGAINST KATHLEEN \\ RAINE'S BLAKE AND ANTIQUITY
}

Brno Studies in English

Volume 46, No. 1, 2020

ISSN 0524-6881 | e-ISSN 1805-0867 https://doi.org/10.5817/BSE2020-1-14

\section{KREŠIMIR VUNIĆ}

\begin{abstract}
William Blake's Marriage of Heaven and Hell is a text that can easily be misinterpreted and this is primarily due to its register and tone; Blake has written a text in which what appears to be mystical insight may blind the reader to a misunderstanding of its major themes. The arts, and specifically the art of poetry and the relationship between the artist and society are what are central in this text, as well as a meditation on the nature of human experience. Beginning with a polemic against Kathleen Raine's statements in Blake and Antiquity, what will be explored here will be the contextual framework of Blake's poetics in this text and their further implications.
\end{abstract}

Key words

William Blake; art; poetry; the senses; society; myth; experience

The purpose of our paper is threefold: beginning with a brief introduction on the place of this work in Blake's career as poet and artist, we will turn to the pioneering work on Blake by G. K Chesterton and Kathleen Rain respectively. Despite the almost half century separating these two separate works on Blake, what we will attempt here is to show how Chesterton's reading saves Blake's work from the kind of misreading as found in Kathleen Rain's Blake and Antiquity in which Blake's meditations on art and society are subjugated to an interpretation which would see Blake's work as a mystic tract. What will follow is an attempt to prove that what is most central to Blake's work are what he had to say primarily on the imagination as relating to art, and to position Blake's conclusions in the context of the thought of his time. The third part of this paper is an analysis of a portion of Blake's text that has rarely figured in discussions of this particular work and how it relates to both Raine's reading of Blake and what we have understood of Blake's aesthetic.

It is no wonder William Blake's Marriage of Heaven and Hell (1790) is a work which will always remain popular and the reasons for this are quite obvious: its title alone portends an apocalyptic fervour, perhaps a narrative (or a description) of the union between loci entirely opposite and most central, not only to the tradition of Christianity, but also as descriptors of states of being. On its own, the word marriage also implies an erotic union sanctioned by the divine. This work, unlike the other of Blake's minor prophecies to which it belongs, is 
predominantly written in prose, making it somewhat of an anomaly in Blake's entire opus.

Furthermore, Blake's constant recourse to the theme of 'restrained' desire, applicable to so many different realms of human life, has lost none of its importance in our day and age: anger against injustice, the aspirations of the artist burdened by the weight of his or her vision, as well as the realm of human sexuality and the desire for bodily and spiritual fulfilment are just some of the themes found herein. According to Peter Ackroyd, the Marriage of Heaven and Hell is among Blake's first works in which the conceptual and aesthetic foundations of those which were to follow are openly declared (described by Ackroyd as a "continually forming myth" (1999: 174)) and is also an ostensibly unguarded manifest of intellectual and spiritual independence (1999: 155). The language here is one of the utmost affirmation so it is no surprise that aphorism and epigram constitute such a significant portion of the text: although appearing as words of proverbial wisdom, their purpose is to subvert the commonplace notions to which they allude. What is also important for the reader to bear in mind, Ackroyd claims, is that in all nine surviving copies of the Marriage of Heaven and Hell Blake's name is entirely absent and that, because of the gnomic nature of much of its utterance, this is entirely intentional (1999: 155).

As can be gathered from the previous paragraph, the Marriage of Heaven and Hell is a work so abundant in ideas and argument that any attempt to make a paraphrase of it is impossible and the fact that Blake had published it anonymously also means that his intention was to tell the reader that what this volume contains is not mere opinion but truth. Some of the thinkers which Blake cites in the Marriage of Heaven and Hell belong to the western esoteric tradition: these thinkers certainly were not read by a wide readership in Blake's time and today are read only by specialists. This has (among other aspects of Blake's work and thought) resulted in the popular view of Blake as a mystic or a writer of works of mysticism and what this means is not difficult to ascertain: the spiritual is given precedence over the physical or the material, a world of matter is to be taken as a world of illusion and there is a marked division between those initiated and the general rabble. One may also take terms such as mystic and mysticism as implying that a writer of such works has a desire for obfuscation, using a language purposely denying easy access. This could not be further from the truth in Blake's case.

This was exactly the point expressed by G. K Chesterton in his study of the life and work of William Blake from 1910, in which he claims that a misunderstanding of the primary intentions of Blake's work and thought are the result of a "verbal accident" (1920: 131); the adjectives mystic and mysterious have long been confounded in the minds of many (and not just the readers of Blake): "Some quacks have indeed dealt in such things: but no true mystic loved darkness rather than light. No true mystic ever loved mere mystery. The mystic does not bring doubts or riddles: the doubts and riddles exist already. We all feel the riddle of the earth without anyone to point it out. The mystery of life is the plainest part of it" (1920: 131). The clarification and illumination of the aporia of existence are essential in Chesterton's statement, and, if we are to follow Chesterton rightly, essential when approaching Blake's work and aesthetic. 
Yet this does not entirely explain how one is to understand the literary context of Blake's work and if this were to be left out of mind, misinterpretations can occur as is this case in Kathleen Rain's study of Blake's symbolism Blake and Antiquity (which is itself a summation of the most important points she made in her much larger volume Blake and Tradition from 1969). Here she comments on plate 21 of the Marriage of Heaven and Hell (2002: 75) in which Blake states:

Any man of mechanical talents may from the writings of Paracelsus or Jacob Boehme, produce ten thousand volumes equal value with Swedenborg's and from those of Dante or Shakespeare, an infinite number. (Blake 1990: 192, 193)

Kathleen Raine does not include this entire passage, not citing the part in which Dante and Shakespeare are mentioned. On the basis of this truncated citation she goes on to add: "we may gather that what fired Blake's imagination in the Alchemical philosophy was the teaching of the famous Smaragdine Table of Hermes Trismegistus..." and claims in an earlier chapter, titled the Myth of the Great Year, that Blake "considered Paracelsus as great as Shakespeare..." (2002: 54).

Should we return to plate 21 in its entirety, it is apparent that such a reading is unjustified, also providing little insight into what Blake meant by "mechanical talents". By mechanical Blake means two things; a talent due to habit only, one that is most easily manifested in the repetition of a certain action and this connects it to its second meaning: a talent that belongs to those of the handicrafts, yet neither meaning can be taken entirely literally. Here Blake is referring to what his primary vocation was for most of his adult life: that of an engraver, also making reference to the entire painstaking process involved in the production of his illuminated books, a process which he terms in plate 14 of the Marriage of Heaven and Hell as his "infernal method" (Blake 1990: 190).

The work which provided Blake with an income for himself and his wife Catherine, as well as the works that he deeply believed to be the truest possible expression of his art, are seen here as belonging to something much greater than what the market may have demanded, as what Blake produced by the means of his mechanical talents not only belongs to the visual arts (these requiring mastery of a set craft), but also to the arts of the word: to poetry. Following this it is possible to elucidate why both Dante and Shakespeare are ranked much higher than either the alchemist Paracelsus or the mystic Jacob Boehme: a system either of alchemy or mysticism remains enclosed within the boundaries of its own conceptual framework, yet Blake claims that much in their works is suggestive enough that it can be disseminated in works of a different medium. Poetry, on the other hand, is, in itself, neither system nor dogma, and Blake's meaning here is that its ability to inspire any artist in any medium is so much greater.

The number of Shakespearean and Dantean allusions found throughout Blake's work are certainly numerous and it is definitely a point of interest that Blake undertook the endeavour to illustrate certain episodes from the Divine Comedy in 1818 (after he had completed his greatest works as a poet), yet there is a definite reason why Shakespeare and Dante are noted as sources of Blake's inspiration 
and why he claims that they can be an inspiration to others: this is because Blake sees the entire opus of both respective poets as anagogic in Northrop Frye's use of the term as "relating to literature as the total order of words" (Frye 1990: 365). The scope of such works goes beyond genre, epoch, period or movement, but includes every aspect of human existence, human and divine: in the preface to Frye's pioneering study of Blake Fearful Symmetry (from 1947) anagogic literature is also termed literary cosmology and this phenomenon has a twofold sense: “... there are two kinds of cosmology, the kind designed to understand the world as it is, and the kind designed to transform it into the form of human desire" (1990: ii). Influence, following Blake's understanding of Dante and Shakespeare, is too weak a word to describe the effect that the works of both writers can have on the artist and reader. Blake continues on the nature of poetry in plate 11 and due to the closeness of its argument, it is necessary to quote it in full:

The ancient poets animated all sensible objects with Gods and Geniuses, calling them by the names and adorning them with the properties of woods rivers, rivers, mountains, lakes, cities, nations, and whatever their enlarged \& numerous senses could perceive.

And particularly they studied the genius of each city and country, placing it under its mental deity.

Till a system was formed, which some took advantage of \& enslav'd the vulgar by attempting to realize or abstract the mental deities from their objects; thus began Priesthood.

Choosing forms of worship from poetic tales. And at length they pronounced that the Gods had orderd such things.

Thus men forgot that All deities reside in the human breast.

(Blake 1990: 186)

In this passage Blake provides us with a narrative of the descent of poetic inspiration into the oppressive confines of institutionalised religion. This descent cannot be taken in a purely historical sense, so it is important to follow both Blake's specific pattern of thought as well as his vocabulary. The words here demonstrate a clash of opposing concepts: animated (a poetic act) is opposed to orderd (a priestly act), system is opposed to poetic tales, calling and pronounced are also opposed, and the act evoked by the verbs realize and abstract are a travesty of the meaning of the word mental in line seven of plate 21 .

Blake sees the inspiration which leads to poetry and the numerous mythoi of any religious tradition as being one and the same. There is no allusion to a definite locus or historical parallel in this passage, meaning that this is a process which had occurred, and can reoccur anywhere and at any time. Furthermore, there is a correspondence between sensible objects and enlarged Eं numerous senses, meaning that the animating act described in the first paragraph of plate 11, was and is inevitable, yet in order to gain a better understanding of this passage it will be necessary to turn to the series of aphorisms Blake composed in $1788 \mathrm{All}$ Religions are One. We will cite Blake's first, fourth and fifth principle from this text. In the first Blake states: 
That the Poetic Genius is the true man. and that the body or the outward form of Man is derived from the Poetic Genius. Likewise that the forms of all things are derived from their Genius, which by the ancients was call'd an Angel \& Spirit \& Demon. (Blake 1990: 77)

The source of the creative impulse is also the source by which experience forms itself into a coherent whole. The outward form of Man, as this aphorism explicitly shows is the body, yet what Blake is stating here is not that that poetic genius is the origin of the material body, but that the body, by the poetic genius, is experienced by the individual as his or her own body, which ultimately leads to the possibility of personal and further narratives.

What Blake is also claiming here is that an absolute dichotomy between the body and the interior (be it named Poetic Genius, Spirit or Demon if we are to follow Blake) is a fallacy. Greene attempts to see the consequences of this and makes the following conclusions, proposing that the Poetic Genius is "a power which is both internal and external" (2005: 69), yet if we are to gain any understanding of what is to be understood by power it is necessary that we turn to the second and third paragraph plate 3 Of the Marriage of Heaven and Hell:

Without Contraries is no progression. Attraction and Repulsion, Reason and Energy, Love and Hate, are necessary to human existence.

From these contraries spring what the religious call Good \& Evil. Good is the passive which obeys Reason. Evil is the active springing from Energy.

(Blake 1990: 181)

Human existence is the term by which Blake desires to break the dichotomy between the internal and the external, and that all that Blake has enumerated here is involved in and necessary to human existence. Blake's understanding of how the religious have interpreted these contraries is that all aspects of human existence are seen as exclusive, thus perpetuating the dichotomy between the body and the interior: the consequences that this has for the realm of the aesthetic and for the impulse which leads to the creation of myth (and eventually religion) is far-reaching.

Northrop Frye has described this process in the following way: "The fight between Devils and Angels is a fight between the two opposed principles of selfdevelopment and Selfhood, and because each springs from the self the latter may spring from the former and imitate its processes" (1990: 71). According to Frye, what this means is that progress is self-development, whereas Selfhood is stasis: Angel and Devil are names for what is in fact one and the same. Despite Frye's acute understanding of this passage, the terms self-development and Selfhood may lead to the conclusion that Blake's concern was primarily the subjective domain of personal experience, yet the scope of this is much greater. Greene, also inquiring into the meaning of the texts cited here, interprets this as follows: "It is the Poetic Genius which allows human inquiry to proceed from the known to the unknown and the fact that science has resulted in an acquisition of knowledge proves, for Blake, that this Genius exists" (2005: 69). Greene's reading is justified 
when compared to principle 4: "As none travelling over known lands can find out the unknown. So from already acquired knowledge Man could not acquire more. therefore an universal Poetic Genius exists" (Blake: 1990: 77).

The personal domain was definitely important to Blake but also a different and radical understanding of the nature of objective (scientific, following Greene) knowledge. Blake's intention is to make the reader see that every aspect of human existence in nuce is a seed for the process for the rejuvenation of every human endeavour: this potential exists in all men (bearing in mind that the Poetic Genius is universal according to Blake), yet the reality is one of denial.

Principle number 5 is the one most directly linked to plate 11 , which only furthers Blake's argument that religion is ultimately a creative act, also breaking the dichotomy between the impulse which establishes myth (and ultimately religion) and poetry (and all artistic endeavour): "The Religions of all Nations are derived from each Nation's different reception of the Poetic Genius which is every where call'd the Spirit of Prophecy" (Blake: 1990, 77). The reception Blake mentions here is linked to Blake's understanding of the contraries and also to the particular historical instance of each nation, and this includes established and institutionalised religion and (recalling Greene) the position and advancement of the Sciences in every particular nation; this also includes the relationship between the arts, sciences and their relation to structures of power.

On the relationship between the artist and the religious culture to which he or she might belong, Frye claims the following: "Now just as the poet is brought up to speak and write one particular language, so he is brought up in the traditions of one particular religion. And his function as a poet is to concentrate on the myths of that religion, and to recreate the original imaginative life of those myths by transforming them into unique forms of art" (1990: 118). The reasons why the recreation of the original imaginative vision is to be attempted at all is so that the imaginative life be allowed a process of renewal and that the institutional structures which now have myth within its grasp (maintaining it in a stagnant and ossified state, oppressing the imaginative life and denying the possibilities of social change) be cleared away. Frye's interpretation also enables us to see the meaning behind Blake's statement in the first paragraph of plate 11: "the ancient poets animated all sensible objects...whatever their enlarged \& numerous senses could perceive". This statement also provides further depth to the breaking of the dichotomy between body and interiority in All Religions Are One.

Thus far we have attempted to analyse the connection between Blake's statements on art in the Marriage of Heaven and Hell with those in All Religions Are One. It is interesting to note that Frye saw a parallel to Coleridge's definition of the secondary imagination in the Biographia Literaria, yet a closer parallel to Blake's view can be found in a work of a somewhat later date: P.B. Shelley's A Defence of Poetry from 1821. What relates it to Blake are Shelley's meditations on the importance of poetry in history and also that Shelley's criticism of his own historical instance is just as passionate. The following quote provides such an instance:

Poetry enlarges the circumference of the imagination by replenishing it with thoughts of ever new delight, which has the power of attracting 
and assimilating to their own nature all other thoughts, and which form new intervals and interstices whose void forever craves fresh food. Poetry strengthens the faculty which is the moral organ in man in the same manner as exercise strengthens a limb. (Shelley 2009: 682)

In this passage Shelley also focuses on the decay and ossification of the mind of man, society, the arts, and social and religious institutions through the passage of time. The parallel between Blake and Shelley is at its most clear in Shelley's use of enlarges: Blake speaks of ancient poets with senses enlarg'd, the creative act being one which animated all objects of perception, the consequence of this which was to be the fullest possible reception of the poetic genius. The enlargement of the circumference of the imagination which Shelley speaks of here is exactly the same process and act. M. H. Abrams has traced the importance of the imagination not only in Shelley's Defence, but also in the many prefaces Shelley wrote for his poems, concluding that for Shelley the "imagination...is the organ by which the individual identifies himself with other people" (1971: 331). Like Blake in his ruminations on the faculty of the poetic genius, Shelley positions the imagination before what he terms the moral organ: a moral circumstance can only be fully understood if it is experienced through an act of recreation, which brings the aesthetic and moral sense into close relation and contact. Yet there are further parallels: the work of the imagination precedes those of the empirical sciences:

The human mind could never, except by the intervention of these excitements, have been awakened to the invention of those grosser sciences and that application of analytical reasoning to the aberrations of society, which it is now attempted to exalt over the direct expression of the inventive and creative faculty itself. (Shelley 2009: 695)

The excitement(s) which Shelley is referring to here is the enlargement of the circumference of the imagination in the passage cited earlier. Shelley, in this passage, attacks what he perceives as the diminishment of the importance of the role of the imagination in the advancement and expansion of knowledge by the sciences of his time in a way parallel to that by which Blake attacks institutionalised religion.

The final section of the Marriage of Heaven and Hell on which we will focus is also its most enigmatic. Conflict and opposition inform its vocabulary, yet as was the case in the earlier passages of the Marriage of Heaven and Hell cited in this paper, the assertive tone requires the reader to look further. Plate 16 begins with what seems to form another aspect of Blake's mythos, yet, as we shall see, a closer reading will uncover that more is at hand than what at first appears:

The Giants who formed this world into its sensual existence and now seem to live in it in chains, are in truth. the causes of its life \& the sources of all activity, but the chains are, the cunning of weak and tame minds. which have the power to resist energy, according to the proverb, the weak in courage is strong in cunning. 
Thus one portion of being, is the Prolific, the other the Devouring: to the producer it seems that the producer was in his chains, but it is not so, he only takes portions of existence and fancies that the whole.

But the prolific would cease to be Prolific unless the Devourer as a sea received the excess of his delights.

Some will say, is not God alone the Prolific? I answer, God only Acts \& Is, in existing beings or men.

These two classes of men are always upon earth, \& they should be enemies; whoever reconcile the two seeks to destroy existence. Religion is an endeavour to reconcile the two. (Blake 1990: 189)

The giants Blake is referring to in the opening paragraph of plate 16 are not to be taken literally and this for several reasons. Firstly, we must return to plate 11 of the Marriage of Heaven and Hell in which Blake mentions enlarg'd and numerous senses, and secondly, Blake uses the present tense, meaning that the giants are here and now. Furthermore, we find that Blake uses a metonym: the chains, are the cunning of weak and tame minds. Blake uses conjunctions such as like or as here because, as mentioned earlier, he has the present moment, our world in fact, in mind, providing this passage with a sense of immediacy. There is a further link between plate 16 and plate 11 in the word-pair senses and sensual: the first word denotes the bodily functions through which sensation is aroused, followed by an adjective meaning that which is dependent on the senses and not on the intellect (or spirit). The word sensual also denotes the pleasurable and the carnal and these further associations are certainly not distant from what Blake is intending here. Blake's use of the word formed remains unclear so that it is necessary to move back through the text in order to elucidate it: it is in fact cognate with the term animated in plate 11. Blake's endeavour is again an attempt to overcome the dichotomy between body and spirit, thus placing the artist at the centre of this argument, as art can only be perceived by the senses and is by its very nature sensual. Blake also proposes that art influences perception (which further aligns Blake's Marriage of Heaven Hell with Shelley's Defence of Poetry)

Yet, as mentioned earlier, conflict and oppression are essential to this passage and the meaning and significance of the prolific and devourer must not remain without a further explication. The root of the word prolific is proles, Latin for offspring (some other words in English which are derived from it are proliferate and proletariat). To be prolific means to produce much or to produce in abundance, whereas devourer has its root in the Latin devorax, with its root in voro, meaning to swallow. Blake himself equates devourer with producer in the third paragraph of this passage and also characterises the prolific and the devourer as two classes, and as we saw a little earlier chains are Blake's metonym for the class of men characterised as the devouring. Blake's intention here is to describe the position of the poet or artist in society and if Blake has described two distinct classes of men then what follows from this is that the devourer represents those in power, politicians, any group of men or women who wield power in any institution which maintains the social fabric, or to express this in Blake's terms: priests. 
For the prolific, what constitutes power is the ability and possibility (we might also add the potency) to realise and actualise what he or she has gained through imaginative insight, vision, or the poetic genius and to pass this on to his or her fellow man. Through the creative act all objects are animated, imbued with spirit and humanised. The artist's creation subsumes all dimensions of time and by doing so affects an intimation of eternity. This is in opposition to power as it is perceived by the devourer: the imaginative faculty must be contracted in order that the devourer's power can be realised. The domains of the human must be seen not only as finite by the devourer but also as limited. The devourer perceives the prolific as being in chains for several reasons: the devourer sees art as belonging to a particular social sector which ultimately means that art is subservient to the state and (which is closer to Blake's original meaning) the devourer cannot see the power of the artist's creation over and in the percipient as the devourer can only perceive power in mundane terms and, by its very nature, the power that the devourer possesses is always oppressive. W.H. Auden, writing in 1939 what was to be a book of aphorisms (although he eventually abandoned this project) under the title The Prolific and the Devourer, made the following comment:

Judges, policemen, critics. These are the real lower orders, the low, sly lives, whom no decent person should receive in his house. (Auden 1981: 18)

It is not Blake's conclusion that the prolific is somehow in a class superior to the devourer, as the fourth sentence in this passage makes clear: “...I answer, God only Acts \& Is, in existing beings or Men”. This statement is purposely general, and when Blake claims 'existing beings or Men' this is expressly what he means. This being the case, the relationship between the prolific and the devourer should also be viewed as one much greater than a relationship which can be subsumed to the nature of political power.

Hazard Adams presents an interpretation which enables the reader to see this section of Blake's text in an even wider context: "One is the purely prolific tendency of the free mythmaking imagination and the other the devouring tendency of the externalizing, purposive object-making and thus subject-making rationality" (2014: 25). Despite the rather abstract nature of Adams' position, when read alongside the closing lines of the second paragraph of Blake's text, it only adds to an expansion of Blake's argument, as Blake states that the devourer "...only takes portions of existence and fancies that the whole".

The prolific overcomes all intellectual, spiritual and (perhaps even physical and historical) dichotomies in the act of "mythmaking" (to use Adams' term), and "mythmaking" for Blake has exactly the same meaning as the creation of art (poetry in particular), yet Blake is also aware that for the vast majority of mankind such dichotomies are inevitable. In the light of what has just been stated the fifth paragraph of this passage gains further meaning and can only expand upon what has been stated concerning plates 16 and 17. In this instance, if the prolific and the devourer were to be reconciled "mythmaking" would be compromised, while for the devourer the primary dichotomies of thought can only maintain their initial rigidity. 
In conclusion, what we have attempted here is to provide the intellectual context for an understanding and interpretation of William Blake's Marriage of Heaven and Hell. Due to the nature of its utterance it is a work which can easily be mistaken for one in which mysticism or the mystical experience is given precedence over art and the art of poetry in particular. We have cited and elaborated from the work of Katherine Raine as an example of such a work. Our analysis has shown that central to the Marriage of Heaven and Hell is the exposition of a poetics in which the arts (and poetry in particular) are of the greatest importance for the rejuvenation of the many facets of human existence, not only limited to religion and politics but to the very sensual experience of life itself.

\section{References}

Abrams, M. H. (1971) The Mirror and the Lamp. Oxford: Oxford University Press.

Adams, Hazard (2014) Thinking Through Blake: Essays in Literary Contrariety. Jefferson:

Macfarland and Company Inc.

Auden, W. H. (1981) The Prolific and the Devourer. Hopewell: Ecco Press.

Blake, William (1990) The Complete Poems. Harmondsworth: Alicia Ostriker editor, Penguin Books.

Chesterton, G. K. (1910) William Blake. London: Duckworth and Co.

Frye, Northrop (1990) Anatomy of Criticism. Princeton: Princeton University Press.

Frye, Northrop (1990) Fearful Symmetry: A Study of William Blake. Princeton: Princeton University Press.

Green, Mathew J. A. (2005) Visionary Materialism in the Early Works of William Blake: The Intersection of Enthusiasm and Empiricism. Basingstoke: Palgrave and Macmillian.

Raine, Kathleen (2002) Blake and Antiquity. New York: Routledge Classics.

Shelley, Percy Bysshe (2009) The Major Works. Zachary Leader and Michael O'Neill, editors, Oxford and New York: Oxford University Press.

KREŠImIR Vunić was born in Bankstown, Sydney, Australia and has been living in Croatia since 1995. He taught at the Faculty of Philosophy at the University of Zadar between 2007 and 2013 and lectured on British Romanticism and English Renaissance Poetry and Drama (particularly on Shakespeare). Since 2014 he has been teaching English as a second language at the Juraj Dobrila University in Pula and is currently working on a doctorate on the works of the American poet John Berryman.

Address: Krešimir Vunić, Department of English Language, Faculty of Philosophy, Juraj Dobrila University in Pula, I. Matetića Ronjgova 1, 52000 Pula, Croatia. [email: kvunic@ unipu.hr] 